Dunja Nešović

\title{
Bottom Text of RuPaul's Drag Race: Reality TV shows and Internet Memes
}

316.775/.776:7.097]:004.5

DOI 10.18485/fdu dhkum.2021.ch14

\section{Introduction}

This paper aims to map out the key elements of the television program RuPaul's Drag Race (RPDR) that makes its content receptive and inviting for online memetization. First, some attention will be devoted to the digital environment of the show itself, since it represents a starting point for further (re)production of digital $R P D R$-based content. Additionally, the digital environment marks a fertile ground for the development of convergence culture. Convergence marks a paradigm shift in the ways content is produced, distributed, consumed, as well as reproduced by blurring the lines between producers and consumers. This paper aims to inspect how the convergence practices are implied already in the content of $R P D R$, namely by making it memeable. In order to do so, a brief overview of the contemporary media theory that looks into audiencetext interaction will be provided, which describes and analyses the notions of memes, spreadable content, and producerly text. Lastly, these theoretical concepts will be applied in analysis of RPDR.

RuPaul's Drag Race is an American reality TV show in which drag queens compete for the title of America's Next Drag SuperStar. The show is named after its host, judge and one of the producers RuPaul Andre Charles, a drag queen, and model who came to prominence in the 1990s. RPDR is produced by WOW Presents and 
started airing in 2009 on Logo TV, before subsequently being transferred to VH1 in 2017. It fits the format of a competitive reality TV show. In each weekly episode, one contestant is eliminated and one is pronounced the winner, which ultimately paves the way to the season's finale and the crowning of the show's winner. The show is directly modeled after, and often referenced to America's Next Top Model (a competitive reality show featuring fashion models) and Project Runway (a competitive reality show featuring aspiring fashion designers). Every episode is followed by an after-show episode of Untucked, which presents the queens backstage, before the elimination. In 2012, apart from airing its regular seasons, RPDR introduced a parallel show called RuPaul's Drag Race All Stars, in which participants of earlier seasons compete against each other for their place in Drag Race Hall of Fame. The show also had a spin-off called Drag $U$, that featured everyday women who were put in drag and taught how to be "fierce" by their drag professors, which were previous contestants of the show.

\section{Digital Environment Of The Show}

RuPaul's Drag Race turned out to be a hit, though not measured by traditional TV popularity metric. When RPDR first started airing, it aired on cable television station Logo TV, which was available in less than half of all American households (Gudelunas, 2017: 231). However, alternative online metrics, such as online episode streaming counts, site visits, retweets and page views, established $R P D R$ as a prime example of television content that thrives in the new media environment ${ }^{1}$. Every episode of $R P D R$ is followed by YouTube videos, also produced by WOW Presents, that address and complement the episode, either by interviewing the eliminated queen (Whatcha packin' with Michelle Visage), making a fashion review of the featured outfits (Fashion Photo Ruview) or by having

1 Season 8 premiere had 1.5 million streams of the episode, a $205 \%$ increase in unique website visitors, and a $357 \%$ increase in page views at LogoTV.com (Walsten, 2016). 
previous contestants give their opinions about the course of action in the episode (Pit Stop). Direct calls to digital participation and interaction are common during an episode of $R P D R$, whether by instilling a Twitter hashtag people can use for discussion, or by asking the audience to vote for their favorite queen. Sometimes, the Internet and social media are integrated into the episode's content. For example, in episode 10 of season 10, Social Media Kings to Queens, the participants were to give drag makeovers to social media influencers, as the producers cleverly sought cross-media and intertextual storytelling to broaden the audience. These strategies represent a model of an integrated system of watching, in which social media plays a central role (Moe et al., 2016: 100).

The audience participation is not limited to the show's specific calls to action, as social networks are used by the fans to share, remix and adapt the content on their own terms. That kind of activity is visible in what James Paul Gee named affinity spaces - specially designed virtual spaces constructed to tie together people with common interests (Buchel, 2012: 45). In this case, they can take the form of a Facebook group, page, Instagram profile, or sites such as Reddit. In all of those spaces, fans can talk about the show, share content and information, as well as create their own. Discussions, commenting, and even making conspiracy theories are all part of fans' interactivity with the content and amongst themselves, but the most noticeable exchange happens through sharing memes. Limor Shifman defines Internet memes as "a group of digital items sharing common characteristics of content, form, and/or stance, which were created with awareness of each other, and were circulated, imitated, and/or transformed via the Internet by many users" (Shifman, 2014: 62).

The subreddit $r$ /rupaulsdragrace has more than 213,000 subscribers with its every other post being a meme; Facebook page RuPaul's Drag Race Family has more than 400,000 followers and a Facebook group RuPaul's Drag Race Fans Memes and Reactions generates more than 40 posts a day ${ }^{2}$. The importance and impact of

2 I chose these virtual spaces as they are the most representative in terms of numbers, but there are numerous Instagram profiles dedicated to 
memes as the indicator and generator of popularity has also been noted by those directly involved with the production of the series. Carson Cresley, the television personality and one of the judges on the show, asked the contestants of the All Stars 4 season, in an interview for BUILD Series, if they think this season will deliver on memes, since the last two seasons did so well with producing content for online memetization. The show's recognition of its memetic potential is also evident in the fact that they use memes on Twitter as a mode of self-promotion.

The digital environment has proved itself to be a catalyst to what Henri Jenkins named the convergence culture. Convergence "alters the relationship between existing technologies, industries, markets, genres, and audience" as well as "the logic by which media industries operate and by which media consumers process news and entertainment" (Jenkins, 2006: 16). On one level, convergence can operate through fans dissecting, repurposing, and distributing content via the Internet (Ibidem). On another, it changes the ways the content is conceived, produced, and delivered to the audiences (Ibid: 18). It is a two-way process that puts the consumers in roles of producers and circles back to the original producers that adapt the media texts in accordance to the types of engagement which proved itself to be the most prolific. The previous segment focused on explaining how the digital environment shapes and situates the convergence practices from both the producer's and consumer's sides. Not only can memes be understood as a derivative of the convergence culture, the way $R P D R$ is created already presumes the future involvement of the viewers with the content. In order to explain links between the two, the next segment will elaborate on the notions of memes, spreadable media, and producerly text.

RPDR fandom and memes as well as other Facebook pages and groups. The meme exchange also happens in more broader contexts, outside of specially constructed spaces - like on Twitter, but those posts are usually marked by and connected with a hashtag. 


\section{Memes, Spreadable Media, and Producerly Text}

The most general characteristic of a meme, a term which was first introduced in 1976 by Richard Dawkins in The selfish gene, is its potential to be replicated and mutated. Internet meme always represents a collection of texts, which differentiates it from a viral - a single unit of digital content that gained huge popularity online (Shifman, 2013: 56). In the digital sphere, memetization happens by repackaging content through mimicry or remix. Mimicry involves a recreation of a text, while remix adds another layer of meaning on top of the original text (ibid: 20). There are three dimensions people could potentially imitate - content (ideas and ideology behind the text), form (physical form of a message), and stance (ways in which potential addressers position themselves in relation to the text) (ibid: 40). Memetic activities play an important role in constructing shared values in contemporary digital cultures (ibid: 60). Memetic texts are the ones that invite the audience to fill in the gaps with their own meanings, presenting themselves as a good starting point for further recreation. They can be categorized as what John Fiske identified as a producerly text, and what was later referred to as spreadable media by Jenkins et al (ibid: 86).

Spreadable media is a term coined by a group of authors (Jenkins, Ford \& Greene) in the book Spreadable media - Creating value and meaning in a networked culture. It represents the type of content people want to engage with and spread across social media platforms. By engaging with content in such a way, fans express belonging to participatory culture - the culture of spectating which implies interaction with the television text by means of cultural production and social interaction (Jenkins et al., 2013: 3). Spreadability recognizes the importance of social ties, which are made more tangible with the use of social networks, and emphasizes producing content in easy-to-share formats. Texts circulate for different purposes and they invite people to shape the context of the material as they share it within their specific social circles (ibid: 6). For content to be spreadable, it has to be available when and where the audiences want it; to be quotable (editable by the audience) and grabbable (easily picked up and inserted elsewhere) (ibid: 198). 
Since the spreadability of certain content is connected to the potential strengthening of social ties between the people who share it, I will mention a few characteristics that could reinforce its spreading. Shared fantasies presented in the text will address the common history and experiences of a community they address. Humor is also one of the indicators for spreadability because it articulates and validates the relationships between the people who share the joke (ibid: 205). Parody and references imply that the ones involved not only get the joke but also share the same knowledge and experience necessary for their comprehension (ibid: 207).

The text with a higher potential for spreadability is a type of text that was earlier defined by John Fiske, in his book Understanding popular culture, as a producerly text. Every popular text is producerly, and that quality differentiates them from other texts of mass culture (ibid: 200). For a text to be producerly, it has to be accessible and understandable, on one hand, and, on the other, it should have the openness which provides possibilities for the audience to encode their own meanings into it (Fiske, 1989: 104). Popular texts are often very intertextual, mostly because they are objects to be treated as commodities minimally crafted on originality. Connecting to each other, and having multiple facets, they act as agents in the social circulation of meaning and pleasure. They are also marked by seriality and repetition, which enables them to fit into the routines of everyday life (ibid: 125).

These notions all refer to one another, as they discuss texts that a) are left open and unfinished, inviting the audience to encode their own meanings into them and $b$ ) address common experience and history of a community which motivates its members to share them amongst themselves. 


\section{Memetic Elements of RuPaul's Drag Race}

\section{Intertextuality and references}

Popular culture is an important base in creating memes and memetic content. On one hand, it provides a reference system that can be used for self-expression which is understandable for others; and on the other, memes are a form of agency used to comment and react to the content of popular culture (Buchel, 2012: 54).

RuPaul's Drag Race builds on numerous TV references and shows that have shaped the American reality TV culture. Its structure includes key elements of other popular reality shows such as America's Next Top Model and Project Runway. They can be obvious like in the case of She-Mail - a cryptic announcement of that week's maxi challenge ${ }^{3}$ referencing Tyra-Mail on America's Next Top Model. RuPaul in male drag, visiting the contestants in the workroom while they prepare for a challenge, strongly resembles Tim Gunn of Project Runway, and in those moments often uses his catchphrase "Make it work". It has been argued that this show doesn't simply borrow from other texts, but instead makes a meta-commentary on the reality genre itself by highlighting every part of its performativity, from the endorsements to RuPaul's false authoritative decision making about who leaves and who stays (Gudelunas, 2016: 236).

The most referenced media text in $R P D R$ is the famous documentary about the drag ballroom scene in New York in the mid-eighties, Paris Is Burning (1990, dir. Jennie Livingston). The discourse used in the show is mostly borrowed from the aforementioned film - runway challenges are often referred to as Balls, Extravaganza, or Realness (the art of passing as another). Reading, a term introduced in the film that signifies a subtle form of insult, is made into a mini-challenge in every season, in which the queens have to "read" one another. Sometimes the words originating from Paris Is Burning are altered and Extravaganza becomes Eleganza,

3 Which is now changed to She done already done had hearses due to controversy of its previous name. 
Psychological becomes Biological, etc., and those kinds of repetitions with mutations constitute a meme in a broader sense (de Villiers, 2012). References to other iconic texts and personalities from queer, as well as popular culture, are often used as a base for creating challenges. Episode 9 of season 7, Divine Inspiration, featured an acting/singing challenge that was based around reenacting (with interventions to the original) famous scenes from John Waters' cult film Pink Flamingos. The concept of the sewing challenge in episode 6 of season 8, Wizards of Drag, was to create outfits that are inspired by characters from Wizard of Oz. Episode 8 of season 10, The Unauthorised Rusical featured a stage musical challenge based on the career of singer and actress Cher. Apart from references to specific texts, some challenges are based on imitating and parodying common television formats like morning programs (season 9, episode 4 Good morning $B^{*}$ tches), news (season 3, episode 5 QNN News), soap operas (season 5 episode 9 Drama Queens) and infomercials (season 6, episode 7 Glamazon by Colorevolution).

The most popular challenge, which is a part of every season since season 2, is the Snatch Game. It is a reference to Match Game, a game show where two contestants try to get as many same or similar answers to questions as the panel of six celebrities. This challenge is modeled as a meme, since it involves mimicry and alteration, with Match becoming Snatch and queens tasked with celebrity imitations.

Constant use of references that appeal to the audience, whether they appear in the speech or as a part of the narrative, affirms the discourse community which is based around the show, and in the broader cultural sense, around the queer identity. A discourse community is defined as a community created by individuals that share interests, and whose discourse is regulated (Porter, 1986: 38). By integrating other popular texts into its structure, $R P D R$ poses itself as a medium by which people can affirm their belonging to a community by "getting" the reference and its meaning, which could motivate them to further engage with it by creating content that reinforces their affiliation. Nicholas de Villiers even claims that memetic activities on the Internet establish queer passing of culture since they bypass the conservative heteroreproductive 
institutions (such as mainstream media and family) that had in the past disabled the queer cultural continuity between the generations (de Villiers, 2012).

\section{Self-referentiality and repetitiveness}

While the previous section examines how RPDR affirms discourse community, this one maps out the ways it creates (or at least adds up to the existing) discourse. RuPaul repeats his three most famous catchphrases in every episode - "Good luck and don't $\mathrm{f}^{* * *}$ it up!" - in the workroom; "Bring back my girls!" - after she made a decision about the elimination; "If you don't love yourself, how in the hell are you gonna love somebody else?" - at the end of each episode. Repetitiveness is one of the main characteristics of memetic videos, according to Shifman, since it can play an important role in encouraging active user involvement in remaking the content (Shifman, 2013: 83). Contestants are also encouraged to make up catchphrases for themselves as a way of establishing their brand and popularity (Gudelunas, 2017: 236). Those catchphrases that are proven to be made popular are often referenced and repeated throughout the current and later seasons. They could be put as a part of a song in a challenge, spoken by the judges or the contestants in the situations that fit with its meaning, or be completely lip-synched.

Season 5, Episode 2 called Lip-synch extravaganza, featured a challenge in which the queens re-enacted the most popular scenes and catchphrases from previous seasons of the series by lip-synching them. Lip-synch is also a meme genre, based on imitating the form, and this can be read as a show's attempt to interact with the digital trends as well as to affirm its role in them. In season 10, the first eliminated queen - Vanessa Vanjie Mateo had the most memorable exit from the stage by going backward and repeating "Vanjie, Vanjie, Vanjie". That exit became a meme in the online world and was used in numerous photos and videos ${ }^{4}$ and was also

4 Vanjie has earned a separate page on KnowYourMeme.com, under the subcategory of RuPaul's Drag Race - https://knowyourmeme.com/ memes/miss-vanjie. 
memed within the show - contestants and judges imitated that catchphrase in every episode and under different circumstances. RuPaul even wore a necklace that spelled out "Vanjie" as a part of his outfit at the Time 100 Gala.

In the aforementioned Snatch Game, on a few occasions, contestants chose to impersonate participants from the former seasons, as well as judges of the show and RuPaul herself. Some of the runway challenges were based on recreating the most memorable looks of former contestants and RuPaul. Self-referentiality grants users permission to adopt and adapt the content for their own purposes (Jenkins et al., 2013: 205). Based on mimicry, alteration and repetition, the self-referential content of $R P D R$ is modeled as a meme, which could further galvanize the viewers to continue its memetization in their own ways.

\section{Excessiveness and obviousness}

"Excessiveness and obviousness are the central features of the producerly text" according to John Fiske. Excessiveness provides a point of resistance to the norm because it enlarges and parodies it. That is why people find pleasure in excessive; they enjoy the mocking of the standard and its failure (Fiske, 1989: 114). Drag art is excessive in itself; it questions, sensationalizes, and collapses gender norms. The same could be said about RPDR; its iconography is brightly colored, glittery, and shiny; its endorsements are not only obvious but highlighted and the performers' appearance and performances are always over-the-top. Humour, which is an important characteristic of this program and one of the indicators for spreadability, is always campy, parodic, and exaggerated.

Showing the obvious makes the audience fill the gaps with their own meanings. It contradicts the idea of the hidden truth, which can be deceiving and one of the dominant ideology's strategies (ibid: 122). In the case of $R P D R$, reactions of contestants to each other and the situations are rendered obvious with the use of extensive close-ups and intercuts of their commentary made in the confessionals. The most evident display of emotions and 
opinions is easy to be used by the producerly reader to incorporate their own meanings and experiences into and to recontextualize them through the making of digital memes. The obvious and blunt reactions of judges and participants of the show, made into memes, are also part of the RPDR's promotional strategy on Twitter. By recontextualizing its own material and sharing it through official digital channels, $R P D R$ makes a meta-commentary about itself by demonstrating the obvious memetic potential it comprises.

\section{Conclusion}

In this paper, I argued that the prolific Internet memetization of the RPDR is spurred both by the show's unique content and the digital environment it thrives in. The show's format and interactive content that can be streamed on various platforms facilitate tight links with the digital environment. Official episodes and extra content are accessible online, on streaming, and on social media platforms, and thus, easy to get appropriated and repackaged for other purposes. Digital trends and references to the online world are found as recurring elements in every $R P D R$ episode. Those kinds of connections allude to the "digital nativity" of this program and allow endless recontextualizations within the digital sphere.

Apart from the digital environment, the other aspect that influences the online memetic activities of RPDR content lies in its narrative and stylistic components. The memetic potential of the content is found in the elements that affirm the belonging to a community but also allow the viewers to embed their own meanings into it. In addition, some parts of the show are created as memes in a broad sense. By modeling its content in such a way, $R P D R$ makes it easier and more inviting for the fans to engage with it via digital memes.

RuPaul's Drag Race is a prime example of contemporary television content that is conquering the realm of social media and other virtual spaces. As such, RPDR marks a shift in paradigm in the production of television shows, as their popularity and cultural 
relevance are no longer measured by ratings and impressions, but more so by their potential to be recreated, remixed, and rethought by the audience which is not a mere and passive consumer, but an active co-creator. The convergence culture around $R P D R$ is then reflected equally in the producer's distribution practices, consumer's recreation of the content, as well as the creative strategies on both ends that further reinforce that interaction.

\section{References}

Buchel, B. 2012. Internet Memes as Means of Communication. University of Brno, MA thesis.

Daw, S. (2018) “RuPaul Donned a 'Miss Vanjie' Necklace on Time 100 Gala Red Carpet” Billboard. Retrieved from https://www.billboard.com/ articles/news/pride/8390243/rupaul-miss-vanjie-necklace-time100-red-carpet-photo

De Villiers, N. (2012) “RuPaul's Drag Race as meta-reality television” Jump Cut: A Review of Contemporary Media No. 54. Retrieved from https:// www.ejumpcut.org/archive/jc54.2012/deVilRuPaul/text.html

Fiske, J. 1989. Understanding popular culture. New York; London: Routledge.

Gudelunas, D. (2016), 'Culture jamming (and tucking): RuPaul's Drag Race and unconventional reality' in Queer Studies in Media \& Popular Culture, 1: 2, pp. 231-249.

Gudelunas D. 2017. „Digital Extensions, Experiential Extensions and Hair Extensions: RuPaul's Drag Race and the New Media Environment" in Brennan N., Gudelunas D. (eds) RuPaul's Drag Race and the Shifting Visibility of Drag Culture, London: Palgrave Macmillan, pp. 231-244.

Jenkins, H., Ford, S., \& Green, J. (2013) Spreadable Media: Creating Value and Meaning in a Networked Culture. New York; London: NYU Press.

Jenkins, Henry. 2006. Convergence Culture: Where Old and New Media Collide. New York, London: NYU Press.

Moe, H., Poell,T., \& Van Dijck, J. (2015) "Rearticulating Audience Engagement: Social Media and Television" in Television \& New Media no. 17/2, pp. 99-107.

Porter, J. 1986. „Intertextuality and the Discourse Community“ Rhetoric Review, 5(1), pp. 34-47. 
Shifman, L. (2014) Memes in Digital Culture. MIT Press.

Walsten, J. (2016) Season 8 Premiere of “RuPaul's Drag Race” Draws Nearly 1 M Viewers. Broadcasting and Cable. Retrieved from https:// www.broadcastingcable.com/news/season-8-premiere-rupaul-sdrag-race-draws-nearly-1m-viewers-154635.

Paris Is Burning, directed by Jennie Livingston. Miramax Home Entertainment, 2005. DVD.

“10s Across the Board.” RuPaul's Drag Race. VH1. March 22, 2018. Television.

“Divine Inspiration” RuPaul's Drag Race. Logo. April 27, 2015. Television.

“Drama Queens” RuPaul's Drag Race. Logo. April 1, 2013. Television.

“Glamazon by Colorevolution” RuPaul's Drag Race. Logo. April 7, 2014. Television

“Good Morning Bitches” RuPaul’s Drag Race. VH1. April 14, 2018. Television.

“Lip Synch Extravaganza Eleganza” RuPaul's Drag Race. Logo. February 4, 2013. Television.

“QNN News” RuPaul's Drag Race. Logo. February 14, 2011. Television.

“Social Media Kings Into Queens” RuPaul’s Drag Race. VH1. May 24, 2018. Television.

“The Unauthorized Rusical” RuPaul's Drag Race. VH1. May 10, 2018. Television.

“Wizards of Drag” RuPaul's Drag Race. Logo. April 11, 2016. Television.

"The Queens Of "RuPaul's Drag Race All Stars" Dish Season 4 w/ Carson Kressley". BUILD Series. YouTube.

RuPaul's Drag Race (2009), USA: Logo.

RuPaul's Drag Race (2017), USA: VH1.

https://knowyourmeme.com/memes/miss-vanjie

https://www.reddit.com/r/rupaulsdragrace/

https://www.facebook.com/RPDRFamily/

https://www.facebook.com/groups/rupauls-drag-race-fans-memes-reactions-1813894445605290/

https://www.youtube.com/user/WOWPresents 


\section{Dunja Nešović \\ Vrije University, Amsterdam, Holandija \\ PODTEKST RUPAUL'S DRAG RACE: RIJALITI TV ŠOU I INTERNET MIMOVI}

Ovaj rad ispituje veze između televizijskog teksta i digitalnih mimova baziranih na njemu, koristeći primer RuPaul's Drag Race. RuPaul's Drag Race je takmičarski televizijski rijaliti šou u kojem se dreg kraljice takmiče za titulu nove dreg superzvezde Amerike. Šou se u potpunosti razvija u digitalnom okruženju, a njegova popularnost i širi kulturni značaj ne mere se samo televizijskim rejtingom, već i onlajn aktivnošću fanova i gledalaca. To uključuje video streaming, posete veb sajtu, retvitove kao i aktivnu interakciju sa tekstom, što je, kao i u slučaju internet mimova, bazirano na nezvaničnoj i neovlašćenoj diseminaciji i rekreaciji televizijskog sadržaja. Kako bismo objasnili vezu između mimova i sadržaja šoua, analiza je pozicionirana u kontekstu kulture konvergencije, teorijske perspektive u studijama medija koja ističe interakciju između medijske produkcije i potrošnje. Mapirani su narativi, stilski i formalni elementi šoua koji ga čine podložnim i zahvalnim za on-line memetizaciju u skladu sa teorijskim konceptom (re)kreatorskog teksta i razdeljivog sadržaja, a na osnovu rada teoretičara kulture i medija Džona Fiskea i Henrija Dženkinsa (tim redom).

Ključne reči: konvergencija, mim, rijaliti šou, (re)kreatorski tekst, razdeljivi mediji 